\title{
DETECTION OF RAW BUFFALO'S MILK ADULTERATION IN SOHAG GOVERNORATE
}

\author{
EMAN M. SHAKER ${ }^{*}$; ABD-ELLAH A. ABD-ALLA** and MOHAMED Y. ELAREF ${ }^{* * *}$ \\ *Department of Food hygiene, Faculty of veterinary medicine, Sohag University. \\ *** Department of Dairy science, Faculty of Agriculture, Sohag University. \\ *** Department of Animal production, Faculty of Agriculture, Sohag University. \\ Email: milk_121970@yahoo.com
}

\section{ABSTRACT}

Received at: $28 / 10 / 2014$

Accepted: 9/12/2014
A total of 85 raw buffalo's milk samples were collected randomly from dairy shops

$(n=25)$, street vendors $(n=30)$ as well as from farmer's houses $(n=30)$ in Sohag Governorate. These samples were physically and chemically examined in order to determine whether they were adulterated by addition of water, partial skimming of fat, addition of inhibitory substances, preservatives or commercial additives and if they were heat treated or not. So, the samples were analyzed by using automatic milk analyzer (to determine specific gravity, fat \%, SNF \%, added water $\%$ and freezing point). Also, milk samples were examined by general and specific tests to detect using inhibitory substances or preservatives, addition of some commercial additives and heat treatment. The results obtained show that milk samples collected from different sources (dairy shops, street vendors and farmer's houses) were adulterated by addition of water, partial skimming of fat, addition of inhibitory substances and different preservatives and heat treated but in different percentages. The highest percentages of adulteration by all types of adulteration were in milk samples collected from street vendors and dairy shops, respectively. It was concluded that adulteration of milk is a complex problem which is not only affect the human health and high economic costs, but also inhibiting the utilization of useful constituents of milk which are very important for normal body growth. So, raw milk in markets must be screened randomly and periodically for adulteration. Moreover, intensification of the enlightenment among street vendors and shops keepers would greatly reduce the occurrence of this problem.

Key words: adulteration, milk analyzer, formalin, heat treatment

\section{INTRODUCTION}

Milk as it comes from a normal udder of healthy dairy animal ensure agreement with standard public health codes for sanitary quality of milk and contain a negligible number of harmless bacteria. When consumers buy milk they have a right to assume that it will be pure and unadulterated. Hence, there is an obligation on the dairy industry to provide adequate quality control systems. So, the physical and chemical examination of milk is very important to evaluate and judge market milk as it is reliable to adulterate by unscrupulous producers or retailers. The chemical composition of Egyptian buffaloes' milk and it is relation to milk law was firstly studied by Ghoniem et al. (1947).

The most common form of adulteration has been adding water to milk which may be polluted with feces, microorganisms, harmful chemicals and poisonous substances. Also addition of water decrease the milk solids not fat contents specially proteins which is very important for normal growth. So, calculation of added water percentage depends on determination of milk solids not fat (Moore et al., 2012 and Santos et al., 2013).

Furthermore, another important type of adulteration is the removal of fat especially in buffalo's milk which is rich in fat content than cow's milk, the skimming of fat deprive the body from utilization of fat and fat soluble vitamins as A, D, E, and $\mathrm{K}$ which are very important for biological processes and normal growth of body. As well as, the combination of both addition of water and partial skimming may be occur, the economic losses will be higher. Incidence of both types of adulteration has been reported by different authors (Mohamed, 1981; Abdel-Hakiem, 1986; Das and Nag, 1986; Stanescu et al., 1992: Erdelyi and Bekei, 1997; Khan et al., 1999; Abdel-Hamid, 2002; Arora et al., 2004 and Abdel- Sabour, 2007).

In recent years, there is a widespread concern about the presence of inhibitory substances added to milk. 
Inhibitors are considered the undesirable substances added to milk, it classified to 3 main categories which are naturally occurring inhibitors (immunoglobulin and lactoferrin); drug residues (antibiotics and sulfonamides); preservatives and residues of cleansing agents or disinfectants.

Use of unauthorized antibiotics or the failure to follow label direction for approved antibiotics could results in unsafe-antibiotic residues in food products, will potential adverse effects on human health (Pena et al., 1999). The passage of antibiotics into milk from medicated animals causes major problems of quality of raw milk. Some antibiotics can cause idiosyncratic reaction in ultra-sensitive consumers and their exposure may lead to an increase in the numbers of resistant to antibiotic individuals (Dewdney et al., 1991). In addition antibiotics can delay (if not totally prevent) the bacteriological process used in the manufacture of certain dairy products and influence negatively coagulation process (Grunwald and petz, 2004) and affecting the flavor and texture of such products (Ripley, 1999).

On the other hand, addition of preservatives such as boric acid, salicylic acid, hydrogen peroxide, formalin, carbonate and bicarbonate even in minute quantities to improve keeping quality of milk or even to delay spoilage for a considerable period of time is a problem for regulatory bodies from the early history of dairying, the toxic effect and carcinogenic effect are the common serious public health hazards appear as a result of accumulation of preservatives. Therefore, detection of inhibitory residues in market milk deems necessary as it is considered also a common type of adulteration (Santos et al., 2013).

Likewise, it is worthwhile to state that there are many common commercial additives such as; starch and cereal flour, gelatin and skim milk powder. They may be added to milk for increasing its viscosity and overcome the adulteration by remove some components of milk (Moore et al., 2012).

Finally heat treatment of the produced milk may safeguard consumers from being infected with pathogens, but in fact it is act as a common type of adulteration as it covers the unsanitary conditions under which milk is produced, as well as, increasing the keeping quality of milk. Also, many off flavors and denaturation of protein may be occur as a result of milk heating (Draaiyer et al., 2009).

This preliminary study was conducted to detect the adulteration of buffalo's milk which is marketed in dairy shopss, street vendors and farmer's houses in
Sohag Governorate and to evaluate the control measures adopted to prevent adulteration.

\section{MATERIALS and METHODS}

\section{I- Collection of samples:}

A total of 85 random samples of raw buffalo's milk were collected in clean, dry and sterile containers from different sources in Sohag Governorate, including dairy shops (25 samples), street vendors (30 samples) and farmer's houses (30 samples).

\section{II- Preparation of samples:}

Each milk sample $(500 \mathrm{ml})$ was thoroughly mixed before being divided into 4 sub-samples. The first was used for physical and chemical examination; the second was used for detection of incidence inhibitory substances and preservatives, the third was used for detection of common commercial additives, while the fourth was used for detection of heat treatment.

\section{III- Analysis of samples:}

A. physical and chemical examination:

1. determination of specific gravity

2. determination of fat content

3. determination of milk solids non fat percentage

4. determination of added water percentage

5. determination of freezing point

All of them are determined by using automatic milk analyzer (Lactoscan MCC, Lactoscan milktronic) (Draaiyer et al., 2009) in Department of Dairy science, Faculty of Agriculture, Sohag University.

B. Detection of inhibitory substances and preservatives: (Draaiyer et al., 2009).

1. General test for detection of inhibitory substances

2. detection of formalin

3. detection of salicylic acid

4. detection of hydrogen peroxide

5. detection of boric acid and borax

6. detection of carbonate and bicarbonate

C. Detection of common commercial additives: (Draaiyer et al., 2009).

1. detection of starch and cereal flour

D. detection of heat treatment:

by using Storch's test (Lampert, 1975). 


\section{RESULTS}

Table 1: Specific gravity of the examined raw buffalo's milk samples.

\begin{tabular}{ccccc}
\hline \multirow{2}{*}{ Sources of milk } & $\begin{array}{c}\text { No. of } \\
\text { examined } \\
\text { samples }\end{array}$ & Minimum & Maximum & Average \\
\cline { 3 - 5 } & 25 & 1.013 & 1.038 & 1.025 \\
\hline Dairy shops & 30 & 1.013 & 1.033 & 1.025 \\
\hline Street vendors & 30 & 1.015 & 1.046 & 1.027 \\
\hline Farmer's houses & & &
\end{tabular}

Table 2: Frequency distribution of examined raw buffalo's milk samples based on their specific gravity.

\begin{tabular}{|c|c|c|c|c|c|c|}
\hline \multirow[b]{2}{*}{ Range } & \multicolumn{2}{|c|}{ Dairy shops } & \multicolumn{2}{|c|}{ Street vendors } & \multicolumn{2}{|c|}{ Farmer's houses } \\
\hline & No./25 & $\%$ & No./30 & $\%$ & No./30 & $\%$ \\
\hline 1.013 & 1 & 4 & 2 & 6.7 & 2 & 6.7 \\
\hline 1.017- & 2 & 8 & 5 & 16.7 & 4 & 13.3 \\
\hline $1.021-$ & 7 & 28 & 5 & 16.7 & 5 & 16.7 \\
\hline 1.025 & 9 & 36 & 9 & 30.0 & 8 & 26.7 \\
\hline 1.029 & 5 & 20 & 7 & 23.3 & 10 & 33.3 \\
\hline $1.033-$ & - & - & 2 & 6.7 & - & - \\
\hline $1.037-$ & 1 & 4 & - & - & 1 & 3.3 \\
\hline W. N. V. & - & - & 2 & 6.7 & - & - \\
\hline B. N. V. & 24 & 96 & 28 & 93.3 & 29 & 96.7 \\
\hline A. N. V. & 1 & 4 & - & - & 1 & 3.3 \\
\hline
\end{tabular}

W. N. V. = Within Normal Value

B. N. V. = Below Normal Value

A. N. V. = Above Normal Value

\begin{tabular}{|c|c|}
\hline Egyptian Standard & $1.033-1.036$ \\
\hline A.V. & 1.034 \\
\hline
\end{tabular}

Table 3: Fat content of the examined raw buffalo's milk samples.

\begin{tabular}{ccccc}
\hline Sources of milk & $\begin{array}{c}\text { No. of } \\
\text { examined } \\
\text { samples }\end{array}$ & Minimum & Mat \% & Maximum \\
\cline { 3 - 5 } & 25 & 1.2 & 8.7 & Average \\
\hline Dairy shops & 30 & 1.0 & 5.3 & 3.0 \\
\hline Street vendors & 30 & 1.5 & 11.2 & 5.0 \\
\hline Farmer's houses & & & & \\
\hline
\end{tabular}

Table 4: Frequency distribution of examined raw buffalo's milk samples based on their Fat content.

\begin{tabular}{|c|c|c|c|c|c|c|}
\hline \multirow[b]{2}{*}{ Range } & \multicolumn{2}{|c|}{ Dairy shops } & \multicolumn{2}{|c|}{ Street vendors } & \multicolumn{2}{|c|}{ Farmer's houses } \\
\hline & No./25 & $\%$ & No./30 & $\%$ & No./30 & $\%$ \\
\hline $1.0-$ & 1 & 4 & 2 & 6.7 & - & - \\
\hline $1.5-$ & 2 & 8 & 1 & 3.3 & 6 & 20 \\
\hline $2.5-$ & 5 & 20 & 9 & 30 & 2 & 6.7 \\
\hline $3.5-$ & 7 & 28 & 11 & 36.7 & 3 & 10 \\
\hline $4.5-$ & 6 & 24 & 7 & 23.3 & 5 & 16.7 \\
\hline $5.5-$ & 1 & 4 & - & - & 7 & 23.3 \\
\hline $6.5-$ & 3 & 12 & - & - & 7 & 23.3 \\
\hline W. L. V. & 4 & 16 & - & - & 14 & 46.7 \\
\hline B. L. V. & 21 & 84 & 30 & 100 & 16 & 53.3 \\
\hline
\end{tabular}

W. L. R. = Within Legal Requirement.

B. L. R. = Below Legal Requirement

\begin{tabular}{|l|l|}
\hline Egyptian Standard & 5.5 \\
\hline
\end{tabular} 
Table 5: Milk solids non fat percentage of the examined raw buffalo's milk samples.

\begin{tabular}{ccccc}
\hline \multirow{2}{*}{ Sources of milk } & \multirow{2}{*}{ No. of examined samples } & \multicolumn{3}{c}{ Milk solid not fat \% } \\
\cline { 3 - 5 } & & Minimum & Maximum & Average \\
\hline Dairy shops & 25 & 4.45 & 10.80 & 8.16 \\
\hline Street vendors & 30 & 4.03 & 10.12 & 7.87 \\
\hline Farmer's houses & 30 & 4.72 & 12.64 & 8.54 \\
\hline
\end{tabular}

Table 6: Frequency distribution of examined raw buffalo's milk samples based on their milk solids non fat percentage.

\begin{tabular}{ccccccc}
\hline \multirow{2}{*}{ Range } & \multicolumn{2}{c}{ Dairy shops } & \multicolumn{2}{c}{ Street Vendors } & \multicolumn{2}{c}{ Farmer's houses } \\
\cline { 2 - 7 } & No./25 & \% & No./30 & \% & No./30 & \% \\
\hline $\mathbf{3 . 7 5}-$ & 1 & 4 & 2 & 6.7 & 1 & 3.3 \\
\hline $\mathbf{4 . 7 5}-$ & - & - & 2 & 6.7 & 1 & 3.3 \\
\hline $\mathbf{5 . 7 5}-$ & 1 & 4 & 2 & 6.7 & 4 & 13.3 \\
\hline $\mathbf{6 . 7 5}-$ & 7 & 28 & 6 & 20 & 3 & 10 \\
\hline $\mathbf{7 . 7 5}-$ & 8 & 32 & 10 & 33.3 & 4 & 13.3 \\
\hline $\mathbf{8 . 7 5}-$ & $\mathbf{5}$ & 20 & 6 & 20 & 7 & 23.3 \\
\hline $\mathbf{9 . 7 5}-$ & 3 & 12 & 2 & 6.7 & 17 & 56.7 \\
\hline W. L. R. & 8 & 32 & 8 & 26.7 & 13 & 43.3 \\
\hline B. L. R. & 17 & 68 & 22 & 73.3 & & 13 \\
\hline
\end{tabular}

W. L. R. = Within Legal Requirement.

B. L. R. = Below Legal Requirement.

\begin{tabular}{l|r|} 
E. S. & 8.75 \\
\hline
\end{tabular}

Table 7: Added water percentage of the examined raw buffalo's milk samples.

\begin{tabular}{cccccc}
\hline \multirow{2}{*}{ Sources of milk } & No. of examined samples & \multicolumn{2}{c}{ Positive samples } & \multicolumn{2}{c}{ Added water \% } \\
\cline { 3 - 6 } & & No. & $\%$ & Minimum & Maximum \\
\hline Dairy shops & 25 & 21 & 84 & 1.1 & 56.8 \\
\hline Street vendors & 30 & 24 & 80 & 2.7 & 61.4 \\
\hline Farmer's houses & 30 & 17 & 56.7 & 0.6 & 54.8 \\
\hline
\end{tabular}

Table 8: Frequency distribution of examined raw buffalo's milk samples based on their added water percentage.

\begin{tabular}{|c|c|c|c|c|c|c|}
\hline \multirow[t]{2}{*}{ Range } & \multicolumn{2}{|c|}{ Dairy shops } & \multicolumn{2}{|c|}{ Street vendors } & \multicolumn{2}{|c|}{ Farmer's houses } \\
\hline & No./25 & $\%$ & No./30 & $\%$ & No./30 & $\%$ \\
\hline-10 & 5 & 20 & 6 & 20 & 5 & 16.7 \\
\hline-20 & 10 & 40 & 7 & 23.3 & 4 & 13.3 \\
\hline$-\mathbf{3 0}$ & 3 & 12 & 6 & 20 & 4 & 13.3 \\
\hline-40 & 1 & 4 & 1 & 3.3 & 3 & 10 \\
\hline$-\mathbf{5 0}$ & - & - & 2 & 6.7 & - & - \\
\hline-60 & 2 & 8 & 1 & 3.3 & 1 & 3.3 \\
\hline-70 & - & - & 1 & 3.3 & - & - \\
\hline Total & 21 & 84 & 24 & 80 & 17 & 56.7 \\
\hline
\end{tabular}


Table 9: Freezing point of the examined raw buffalo's milk samples.

\begin{tabular}{ccccc}
\hline \multirow{2}{*}{ Sources of milk } & \multirow{2}{*}{ No. of examined samples } & \multicolumn{3}{c}{ Freezing point } \\
\cline { 3 - 5 } & & Minimum & Maximum & Average \\
\hline Dairy shops & 25 & -0.573 & -0.252 & -0.432 \\
\hline Street vendors & 30 & -0.545 & -0.250 & -0.415 \\
\hline Farmer's houses & 30 & -0.682 & 0.260 & -0.467 \\
\hline
\end{tabular}

Table 10: Frequency distribution of examined raw buffalo's milk samples based on their freezing point.

\begin{tabular}{|c|c|c|c|c|c|c|}
\hline \multirow{2}{*}{ Range } & \multicolumn{2}{|c|}{ Dairy shops } & \multicolumn{2}{|c|}{ Street vendors } & \multicolumn{2}{|c|}{ Farmer's houses } \\
\hline & No./25 & $\%$ & No./30 & $\%$ & No./30 & $\%$ \\
\hline$-0.250-$ & 2 & 8 & 4 & 13.3 & 2 & 6.7 \\
\hline$-0.290-$ & 1 & 4 & - & - & 1 & 3.3 \\
\hline$-0.330-$ & 1 & 4 & 3 & 10 & - & - \\
\hline$-0.370-$ & 6 & 24 & 4 & 13.3 & 2 & 6.7 \\
\hline$-0.410-$ & 6 & 24 & 6 & 20 & 6 & 20 \\
\hline$-0.450-$ & 3 & 12 & 7 & 23.3 & 4 & 13.3 \\
\hline$-0.490-$ & 1 & 4 & - & - & - & - \\
\hline$-0.530-$ & 4 & 16 & 6 & 20 & 13 & 43.3 \\
\hline$-0.570-$ & 1 & 4 & - & - & 2 & 6.7 \\
\hline W. N. V. & 4 & 16 & 6 & 20 & 13 & 43.3 \\
\hline
\end{tabular}

W. N. V. = Within Normal Value

\begin{tabular}{|c|c|}
\hline Egyptian Standard & $-0.530--0.560$ \\
\hline AV. $=$ & -0.550 \\
\hline
\end{tabular}

Table 11: Positive results of inhibitory sub, preservatives, commercial additives and heat treatment.

\begin{tabular}{lcccccc}
\hline \multirow{2}{*}{ Items } & \multicolumn{2}{c}{ Dairy shops } & \multicolumn{2}{c}{ Street vendors } & \multicolumn{2}{c}{ Farmer's houses } \\
\cline { 2 - 8 } & $\mathbf{+ v e / 2 5}$ & $\mathbf{\%}$ & $\mathbf{+ v e / 3 0}$ & $\mathbf{\%}$ & $\mathbf{+ v e / 3 0}$ & $\%$ \\
\hline $\begin{array}{l}\text { a- Inhibitory sub .\&preservatives: } \\
\text { 1-General test }\end{array}$ & 25 & 100 & 15 & 50 & 14 & 46.6 \\
\hline 2-Formalin & 15 & 60 & 3 & 10 & 9 & 30 \\
\hline 3-Salicylic acid & - & - & - & - & - & - \\
\hline 4-Hydrogen peroxide & - & - & 1 & 3.4 & - & - \\
\hline 5-Boric acid \& Borax & 10 & 40 & 9 & 30 & 5 & 16.7 \\
\hline 6-Carbonate \&bicarbonate & -- & - & - & - & - & - \\
\hline $\begin{array}{l}\text { b- common commercial additives: } \\
\text { starch \& cereal flour }\end{array}$ & - & - & - & - & - & - \\
\hline c- Heat treatment & 7 & 28 & 11 & 36.7 & 7 & 23.3 \\
\hline +ve = Number of positive samples & & & & & &
\end{tabular}

$+\mathrm{ve}=$ Number of positive samples

\section{DISCUSSION}

\section{A. physical and chemical examination:}

The most common forms of milk adulteration have been by addition of water to milk, partial skimming or both. Those forms of adulteration constituted a problem for market milk industry and continue up to day. So, the physical and chemical examination bay acts to a certain extent as a check.

\section{Specific gravity:}

The result obtained in Tables $1 \& 2$ revealed that the specific gravity of the examined milk samples obtained from dairy shops, street vendors and farmer's houses ranged from 1.013 to $1.038,1.013$ to 1.033 and 1.015 to 1.046 with an average of 1.025 , 1.025 and 1.027, respectively. The highest frequency distribution were $9(36 \%)$ and $9(30 \%)$ of dairy shops and street vendors milk samples lied within the 
ranges of 1.025 to 1.028. Similar results were reported by Abdel- Hakiem (1986), whereas higher results were recorded by Abdel -Hameid (2002) and Abdel- Sabour (2007) While the highest frequency distribution was $10(33.3 \%)$ of the farmer's houses examined milk samples lied within the ranges of 1.029 to 1.032 . These results were in fairly close agreement with Sabry (2006), while were higher than the results obtained by Abdel- Sabour (2007) and lower than that recorded by Abdel -Hameid (2002).

Data in Table 2 noticed that 24 (96\%), 28(93.3\%) and $29(96.7 \%)$ out of dairy shops and, street vendors and farmer's houses examined milk samples gave a specific gravity below the normal value of Egyptian regulated standard (1.033) (Egyptian Standard, 2005) , on the other hand, 1(4\%) and 1(3.3\%) out of dairy shops and farmer's houses examined milk samples, respectively, gave a specific gravity above the normal value of Egyptian regulated standard (1.036) (Egyptian Standard, 2005), while only 2(6.7\%) out of street vendors milk samples which had the normal value parallel to Egyptian standard.

The results reported here below normal values of specific gravity of all types of milk samples may be attributed to adulteration by addition of water. Also, above normal value have been noticed among dairy shops and farmer's houses examined milk samples may be due to adulteration by partial skimming, while, those within normal value of street vendors milk samples may be of normal milk or adulterated by both addition of water and partial skimming.

\section{Fat content:}

In general buffalo's milk is more liable to adulteration than cow's milk as it is rich in fat content which encourage the unscrupulous producers or retailers to remove part of fat content of buffalo's milk.

It is evident from data demonstrated in Tables $3 \& 4$ that the fat $\%$ in dairy shops and street vendors examined milk samples ranged from 1.2 to $8.7 \%$ and 1.0 to $5.3 \%$ with averages of 4.0 and $3.7 \%$, and the highest frequency distribution of $28 \%$ and $36.7 \%$ lied within same range of $3.5-4.4$, respectively. These findings are lower than those recorded by Abdel-Hakiem (1986), Kamel (2000), Abdel-Hameid (2002) and Abdel- Sabour (2007). In case of farmer's houses milk samples, the fat content ranged from 1.5 to $11.2 \%$ with an average of $5.0 \%$. Most of the examined samples $(46.7 \%)$ had fat \% of more than $5.5 \%$, these results are in fair agreement with those recorded by Kamel (2000), while higher than that obtained by Abdel- Hameid (2002).

As seen in Table 4 data reviewed that 21 (84\%), 30 $(100 \%)$ and $16(53.3 \%)$ out of dairy shops, street vendors and farmer's houses examined milk samples, respectively, gave fat content below the legal requirement of the Egyptian standard for buffalo's milk (5.5\%), while the other samples lied within the Egyptian regulated minimum standard (Egyptian Standard, 2005). Concerning the street vendors milk samples, they were the worst one, as about $100 \%$ of samples were adulterated by partial skimming or addition of water.

\section{Milk solids non fat content:}

Results given in Tables $5 \& 6$ revealed that SNF content of dairy shops milk samples ranged from 4.45 to 10.80 with an average of 8.16 and from 4.03 to 10.12 with an average of 7.87 for street vendors milk samples. The highest frequency distribution were $32 \%$ and $33.3 \%$ for dairy shops and street vendors examined milk samples, respectively, which lied within the range of 7.75 to 8.74 for both types. These findings relatively agree with those reported by Kamel (2000) and Abdel- Sabour (2007), whereas higher results recorded by Oyama et al. (1992), Chow and Hu (1997) and Abdel- Hameid (2002). Milk solids non fat percentages of farmer's houses milk samples were ranged from 4.72 to $12.64 \%$ with an average of $8.54 \%$, and the highest frequency distribution $56.7 \%$ ranged from 8.75 to $9.75 \%$. These findings agree with those reported by AbdelHameid (2002).

The gained results specially in case of milk SNF\% showed that $17(68 \%), 22(73.3 \%)$ and $13(43.3 \%)$ of dairy shops, street vendors and farmer's houses examined milk samples, respectively, gave results below Egyptian regulated minimum legal requirement (8.75\%), (Egyptian Standard, 2005), whereas the remaining samples were lied within the Egyptian regulated minimum legal requirement. These results indicated that farmer's houses milk samples were the best one. While, the street vendors samples were the worst. The lower SNF content could be attributed mainly to adulteration by addition of water (Harding, 1995) as it decreases only by addition of water and not affected by partial skimming.

\section{Added water percentage:}

Tables $7 \& 8$ demonstrated that $21(84 \%)$ of milk samples collected from dairy shops had added water content of different percentages ranged between 1.1 to $56.8 \%$, the highest frequency distribution $15(60 \%)$ lied within range of 1 to $20 \%$. whereas, $24(80 \%)$ of street vendors milk samples had added water content ranged between 2.7 to $61.4 \%$, the highest frequency distribution 19(63.3\%) lied within range of 1 to $30 \%$. Moreover, 17(56.7\%) of farmer's houses milk samples had added water content ranged between 0.6 to $54.8 \%$, the highest frequency distribution $13(43.3 \%)$ lied within range of 1 to $30 \%$.

This study mention the presence of added water in varying degree in all types of milk samples which confirmed adulteration of milk by addition of water. Whereas, the highest percentages of samples adulterated with water were $84 \% \& 80 \%$ recorded in 
dairy shops and street vendors milk samples, respectively, with the highest percentage of added water 60 to $70 \%$ in street vendors milk samples only. These results is higher than these recorded by AbdelSabour (2007).

\section{Freezing point:}

Results given in Tables 9 \& 10 revealed that freezing point of dairy shops milk samples ranged from 0.573 to -0.252 with an average -0.432 while ranged from -0.545 to -0.250 with an average of -0.415 for street vendors milk samples and for farmer's houses milk samples were ranged from - 0.682 to -0.260 with an average of -0.467 . The highest frequency distribution were $48 \%, 63.3 \%$ and $43.3 \%$ which lied within the range of $(-0.370$ to -0.440$),(-0.410$ to $0.560)$ and (- 0.530 to -0.560$)$ for dairy shops, street vendors and farmer's houses examined milk samples, respectively.

The gained results (Table 10) showed that only $4(16 \%), 6(20 \%)$ and $13(43.3 \%)$ of dairy shops, street vendors and farmer's houses examined milk samples, respectively, gave results within Egyptian regulated standard (- 0.530 to - 0.560) (Egyptian Standard, 2005), whereas the remaining samples were above the Egyptian regulated standard which could be attributed mainly to adulteration by addition of water only. These findings could confirm the previous results of the percentage of samples had added water obtained in this study (Table 8).

\section{B. Inhibitory substances and preservatives: \\ 1- General test for inhibitory substance and preservatives:}

The results given in Table 11 illustrated that 25 (100\%), $15(50 \%)$ and $14(46.6 \%)$ out of 25,30 and 30 examined samples of dairy shops, street vendors and farmer's houses, respectively were positive for inhibitory substances. Abdel- Hameid (2002), Wahba and Korashy (2006) and Abdel- Sabour (2007) recorded positive results in all types of milk samples but in different percentages. It is obvious from these results that the dairy shopss milk samples had the highest percentage of adulteration with inhibitory substances resembling $100 \%$.

\section{2- Specific tests for preservatives:}

The data represented in Table 11 revealed that all examined milk samples from different sources were free from salicylic acid, carbonates and bicarbonates, while $15(60 \%), 3(10 \%)$ and $9(30 \%)$, of examined milk samples from dairy shops, street vendors and farmer's houses respectively, were treated with formalin. Also the results showed that 10 (40\%), 9 $(30 \%)$ and $5(16.7 \%)$ out of the same samples were positive for boric acid. Whereas, only 1(3.4\%) out of the street vendors samples were treated with hydrogen peroxide. Many studies recorded nearly similar results (Erdelyi and Bekei, 1997; Kamel, 2000 and Abdel- Hameid, 2002). However, Abdel- Sabour (2007) could detect carbonates \& bicarbonates behind formalin, salicylic acid and boric acid. Formalin is a famous preservative for milk because it has the property of being in a liquid form. Also boric acid owing to the fact that boric acid and borax have oxidizing power, 1 part of these substances in 1 to 2 thousand parts of milk is sufficient to preserve milk and to delay curdling for several days.

\section{Common commercial additives:}

D. It is clearly evident that all examined milk samples from all sources were free from starch and cereal flour. These results agree with Abdel- Sabour (2007) while disagree with Arora et al. (2004).

\section{E. Heat treatment:}

Dairy shops, street vendors and farmer's houses examined milk samples showed that 7 (28\%), 11 $(36.7 \%)$ and $7(23.3 \%)$ were heat treated. On the other hand the remainder of milk samples proved to be in raw state. These results were higher than that obtained by Abdel- Sabour (2007), while AbdelHameid (2002) recorded negative results for dairy shops milk samples and lower results for street vendors and farmer's houses milk samples. The results here pointed out that heat treated milk noticed among milk samples from all sources, which may be used to increase the shelf life and keeping quality of milk and to cover its low quality and the bad sanitary measures under which milk is produced. This finding indicates another type of adulteration.

\section{REFERENCES}

Abdel-Hakiem, E.M. (1986): Sanitary conditions of milk, fermented milk, Kareish cheese and butter manufactured in Assiut Province. M.V.Sc., Thesis, Fac. Vet. Med, Assiut, Univ., Egypt.

Abdel-Hameid, Karima, G. (2002): Studies on the sanitary condition of raw milk in Qena Governorate. M.V.Sc., Thesis, Fac. Vet. Med., Assiut, Univ., Egypt.

Abdel-Sabour, R.O. (2007): Detection of Milk Adulteration In Assiut Governorate, M.V.Sc., Thesis, Fac. Vet. Med., Assiut, Univ., Egypt.

Arora, S.; Sharma, V.; Raj, D.; Ram, M. and Kishore, $K$. (2004): Status of milk adulteration in some states of North India. Indian J. Dairy Sci. 57(1): 65-66.

Chow, C. and Hu, T. (1997): Effects of seasonal alteration on somatic cell count and milk quality in cow raw milk. J. Chinese Society of Animal Sc., 26 (1): 87-97.

Das, R. and Nag, N.C. (1986): Examination of market milk collected from Calcutta and neighboring places with special reference to isolation of salmonella. Ind. J. Animal Health. 25(2): 145-149. 
Dewdney, J.M.; Maes, L.; Raynaud, J.P.; Blanc, F.; Scheid, J.P. and Jackson, T. (1991): Risk assessment of antibiotic residues of $\beta$-Lactams and macrolides in food products with regard to their immunoallergic potential. Food Chem. Toxicol., 29(7): 477-483.

Draaiyer, J.; Dugdill, B.; Bennett, A. and Mounsey, J. (2009): Milk Testing and Payment Systems Resource Book: a practical guide to assist milk producer groups. FAO, Rome, Italy.

Egyptian Standards (2005): Raw Milk Egyptian For Standardization. No. 154/2005.

Erdelyi, J. and Bekei, A. (1997): Inhibitor content of raw milk in Hungary with particular reference to new quality requirement. Proceedings of the $3^{\text {rd }}$ Hungarian Dairy Conference on quality, Nyiregyhaza-Sosto, Poland, 4-5 November (1996). Tejgazdzsag (1997), No. Special, 122-133.

Ghoniem, A.; Taha El-Katib, M. and El-Magrabi, M. (1947): Chemical composition of Egyptian buffalo's milk and it is relation to milk law. J. Egypt Med. assoc. 30(8): 418.

Grunwald, L. and Petz, M. (2004): Food processing effects on residues penicillin in milk and yoghurt. Anal. Chem. Acta. 483: 73-79.

Harding, F. (1995): Milk Quality. $1^{\text {st }}$ Ed. Blackie Academic and Professional; Chapman and Hall, New York, London, Tokyo, Madras.

Kamel, Azza, M. (2000): Studies on raw milk quality in Kafr El- Sheik. M.V.Sc., Thesis, Fac. Vet. Med., Tanta., Univ., Egypt.

Khan, M.; Rajah, K.K. and Haines, M. (1999): Quantities techniques in the measurements of milk adulteration in Peshawar, Pakistan. Inter. J. Dairy Technol. 52 (1): 20-25.

Lampert, L.M. (1975): Modern Dairy Products. $3^{\text {rd }}$ Ed., Chemical Publishing Co., Inc., New York. Mohamed, A.M. (1981): Study in the status of raw market milk. M. V. Sc., Thesis, Fac. Vet. Med., Alex., Univ., Egypt.
Moore, T.C.; Spink, J. and Lipp, M. (2012): Development and application of a database of food ingredient, fraud and economically motivated adulteration from 1980-2010. Journal of Food Science, 77 (2012), pp. R118-R126.

Oyama, H.; Arai, Y. and Sasano, M. (1992): Quality of raw milk produced in Hokkaido prefecture during the period from $2^{\text {nd }}$ year of Showa (1987) to $3^{\text {rd }}$ year of Heisei (1991): Jap. J. Dairy \& Food Sc., 41: 3, A107-114.

Pena, A.L.; Lino, C.M. and Silveira, I.N. (1999): determination of oxytetracycline, tetracycline and chlortetracycline in milky liquid chromatography with post column dramatizations and fluorescence detection. J. A. O. A. C. Inter. 82 (1): 55-60.

Ripley, D. (1999): Mastitis. Prim Care Update Ob/ Gyns. 6: 88-92.

Sabry, Y.M. (2006): Sanitary Improvement of Serving Milk And Dairy Products In Assiut Univ, Hospital, Ph.D., Thesis, Fac. Vet. Med., Assiut., Univ., Egypt.

Santos, P.M; Pereira, E.R. and Rodrigyez- Saona, L.E. (2013): Rapid detection and quantification of milk adulteration using infrared micro spectroscopy and chemometrics analysis. Food Chemistry, 138: 19-24.

Stanescu, V.; Savu, C. and Mihaiu, M. (1992): The determination of the physicochemical quality indices of raw milk after milking and the influence of various factors. LucrariStiintifice, universitatea-de StiinteArgonomics, Bucuresti-Seria-C, Medicinavetrinara. 35 (1): 119-129.

Wahba, Nahed, M. and Korashy, Eman, A. (2006): A preliminary detection of inhibitory substances in milk sold in Assiut governorate. Assiut Vet. Med. J. 52 (109): 93-100.

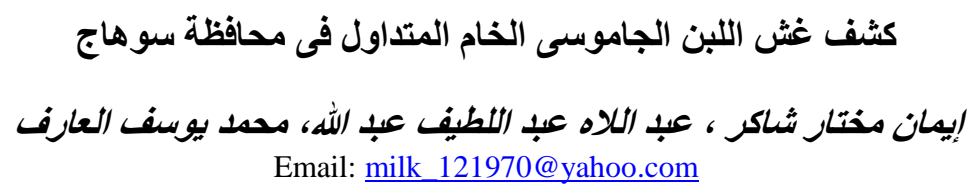

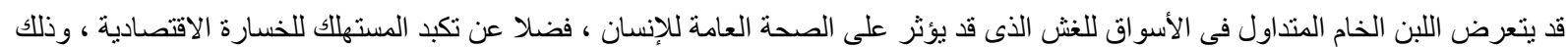

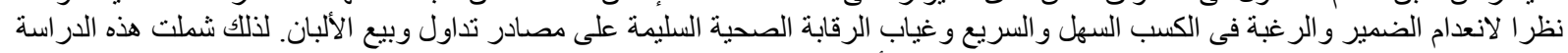

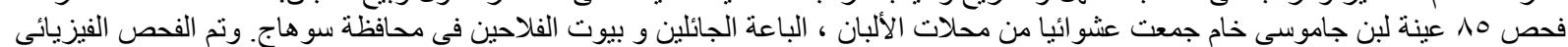

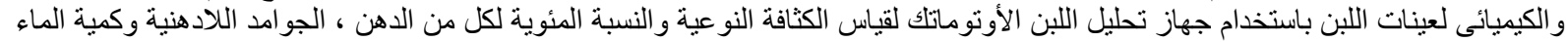

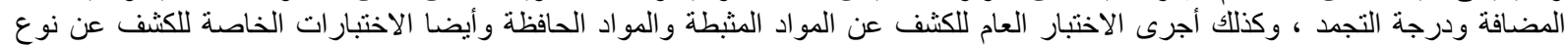

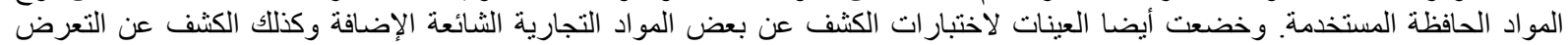

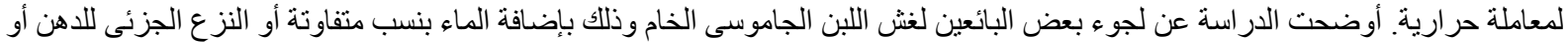

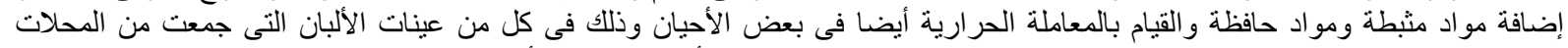

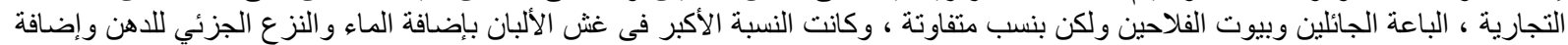

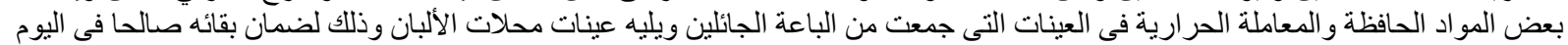

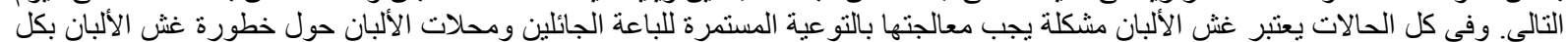

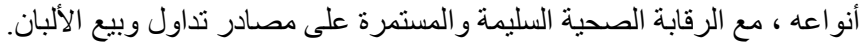

